\title{
FARMING RICE PRODUCTION EFFICIENCY ON FARMING STATUS BY LAND TENURE
}

\author{
Ratna Dewi ${ }^{*}$ 1), Mahludin Baruwadi ${ }^{2)}$, Amir Halid ${ }^{2)}$ \\ 1) Department of Agriculture, Boalemo District, Gorontalo Province \\ 2) Faculty of Agriculture State University of Gorontalo \\ ") Corresponding Author E-mail: ratnadewi07173@gmail.com
}

\begin{abstract}
The study aims to determine (1) the factors that affect rice production in the district was. (2) Efficient use of land, seed, fertilizer, and labor on the fields in the district was usahatanipadi. This research is quantitative. Sources of data in this research are secondary data from the primary data from questionnaires to farmers of paddy in Gorontalo. The data analysis technique used is the Cobb Douglas.These results indicate that (1) the results of the Cobb Douglas found that simultaneous land, seed, fertilizer, labor, and land tenure positive and significant impact on rice production in the district was the province of Gorontalo to the value of the determinant of $79,50 \%$ for tenants and owners of $67,50 \%$ to the tiller. Then the partial results only land, seed and labor are positive and significant impact on rice production in the district was Gorontalo province. The coefficient of land ownership that is positive indicates that farmers with its status as the owner of tenants is better than the sharecroppers in generating optimal production. (2) The results of the technical efficiency analysis shows that the area of land, seed, labor, and land tenure have a greater value than one that is in the category yet efficient (increasing returns to scale). Then for fertilizer has a smaller value than one that is in the category inefficient (decreasing return to scale). The results of the comparison in terms of the land status was found that the owner of tenants is better than the tenants in the efficiency of production input rice production in the district was sawah.
\end{abstract}

Keywords: Production; Seed; Fertilizer; Labor; Size; Status of Land

\section{INTRODUCTION}

Food crops grown by farmers in the district was is rice because rice is the staple food and a source of calories for most residents. According to data from the Department of Agriculture Office Boaleomo 2016 of 7 subdistricts in the district was No 4 Districts are cultivated Rice namely: District Mananggu with an area of 412 ha, District Botumoito with an area of 35 ha, District Paguyaman with an area of 1772 ha, District Wonosari $3027 \mathrm{Ha}$.

Rice production district was volatile during the last 5 years where in 2013 Planted area 9.552 ha, 9.252 ha Harvested with production of 50.828 tons. In 2014, Planted area 6.310 ha, 9.318 ha Harvested production of 52.399 tons. In 2015, 8.025 ha Planted Area, Harvested Area 9.533 ha with a production of 49.513 tons. In 2016, the planting area 11.084 ha, 9.913 ha Harvested production of 55.373 tons. In 2017, 10.631 ha Planted Area, Harvested Area 13.012 ha with a production of 67.541 tons, (Central Bureau of Statistics of Boalemo). It is caused by several factors, one of which is climate change and the use of factors of production.

Efforts to increase agricultural production (rice) have been carried out either by governments, nongovernmental organizations, and universities. But in practice obtained by the fact that the potential yield of rice production is different from the actual results (real) obtained by farmers. The yield difference (yield gap) is largely due to two factors: 
the non-technical factors and technical factors. Non-technical factors are events that prevent farmers using recommended technology. These things include: (1) knowledge of farmers as an indicator is the experience of farmers in farming; (2) transport infrastructure as a distance indicator is the residence of arable land with farmers. While technical factors as the indicator is the availability of irrigation water. Non-technical factors and technical factors that will affect the consideration of farmers as a manager to make decisions on the use of inputs such as seed, fertilizer, labor, and medicine. Thus the non-technical factors and technical factors working simultaneously (together) will determine the farmers in the use of fertilizers, effective labor and drugs that will determine the level of production and productivity of paddy farming.

The problem is that the agricultural program The district was particularly rice production enhancement program can not be separated from the utilization of factors of production. At the present time the production at the farm level is still low at an average of 3.5 tons per hectare where the national standard of 5.1 tons per hectare. This is because the use of factors of production less efficient. Where the use of factors of production that are less precise and efficient in farming would result in lower production and higher costs in the end reduce the income of farmers. Thus the need for management of production factors should consider the optimization principles in order to achieve high production with efficient allocation of factors of production and effective.

\section{METHOD}

This research was conducted in the district was in the month of September 2018 to March 2019. The number of the population by 5030 amounted servey farmers consisting of 517 farmers Mananggu Subdistrict, Botumoito Subdistrict 26 farmers, Paguyaman Subdistrict 1588 farmers, and Wonosari Subdistrict 2879 farmers. To set the number of samples in this study using a calculation formula Slovin so that the total sample of 98 people.

Analysis of the research approach Cobb-Douglass production function. Rice production function model sawahsebagai follows:

$$
\operatorname{Ln} Y_{i}=\ln \beta 0+\beta 1 \ln X 1+\beta 2 \ln X 2+\beta 3 \ln X 3+\beta 4 \ln X 4+e
$$

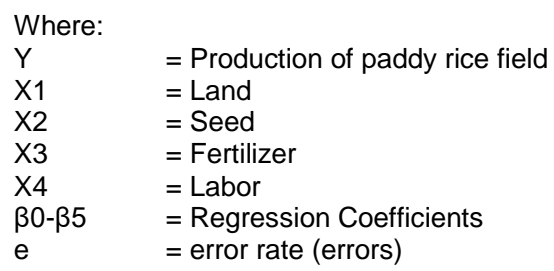

\section{RESULTS AND DISCUSSION}

\section{Influence of Input-Input Farming Against Rice Production in the district was}

The results of multiple regression is shown in the following Table 1:

Table 1: Analysis Model Cobb Douglas

\begin{tabular}{cccccccc}
\hline \multirow{2}{*}{ No. } & \multirow{2}{*}{ Variable } & \multicolumn{3}{c}{ Owner Cultivators } & \multicolumn{3}{c}{ Cultivators } \\
\cline { 3 - 8 } & & $\mathbf{B}$ & $\mathbf{t}$ & $\mathbf{p}$-value & $\mathbf{B}$ & $\mathbf{t}$ & p-value \\
\hline 1 & Constant & -6478 & & & -6743 & & \\
2 & Land area & 0,412 & 4,386 & 0,000 & 0,221 & 2,570 & 0,014 \\
3 & Seed & 0,819 & 4,931 & 0,000 & 1,047 & 6,352 & 0,000 \\
4 & Fertilizer & 0,092 & 1,161 & $0,252 \mathrm{~ns}$ & 0,090 & 0,933 & 0,356 \\
5 & Labor & 0,154 & 2,029 & 0,048 & 0,155 & 2,552 & 0,014 \\
\hline \multicolumn{3}{c}{$48.409(0.000)$} & & $25.393(0.000)$ \\
& F Count & 0,811 & & 0,703 & \\
R S Square & \multicolumn{3}{c}{0,795} & & 0,675 & \\
\hline
\end{tabular}


Testing of production inputs using Douglas Cobb analysis where results can be described as follows:

1) Douglas Cobb Analysis Results

Based on the analysis using SPSS 21 , of Table 4.10 above the regression model is obtained as follows:

a. Equation Cobb Douglas To Own Cultivators

The multiple regression model with the approach of the farmers cobb douglas poadi paddies land status owner cultivators in the district was presented as follows:

$$
\operatorname{Ln} Y=-6.478+\operatorname{Ln} 0,412 X 1+\operatorname{Ln} 0,819 X 2+\operatorname{Ln} 0,092 X 3+\operatorname{Ln} 0,154 X 4
$$

b. Equation Cobb Douglas To Cultivators

The multiple regression model with the approach of the farmers cobb douglas poadi paddies land status cultivators in the district was presented as follows:

$$
\operatorname{Ln} Y=-6.743+\operatorname{Ln} 0,221 X 1+\operatorname{Ln} 1,047 X 2+\operatorname{Ln} 0,090 X 3+\operatorname{Ln} 0,155 X 4
$$

2) Interpretation of Coefficient of Determination

Value Coefficient of Determination taken of Adjusted R Square for the independent variable in this study is more than one variable. Table 1 Based on the above, the value of the coefficient of determination adjusted $R^{2}$ at the owner's position amounted to 0,795 tenants. This value means that $79,5 \%$ the amount of rice production in the district was Gorontalo province can be explained by land, seed, fertilizer, and labor in the district was Gorontalo province. While $20,5 \%$ is explained by other factors beyond the variables studied.

Then the coefficient of determination adjusted $\mathrm{R} 2$ on the tiller position at 0,675 . This value of $67,5 \%$ means that the amount of rice production in the district was Gorontalo province can be explained by land, seed, fertilizer, and labor in the district was Gorontalo province. While $32,5 \%$ is explained by other factors beyond the variables studied.

Other factors that are out of production function model which allegedly also have an impact on rice production include soil fertility level and the influence of weather and climate as well as the intensity of pests and diseases.

3) Simultaneous Test Results (Test F)

This test is to determine the effect of independent variables together on the dependent variable. Based on Table 1 above in land tenure owner tillers obtained value Fhitung this study amounted to 48.409 with a significance level (Probability Value) of 0,000 and for the ownership status of land tenants values obtained Fhitung this study amounted to 25.393 with a significance level (Probability Value) of 0,000 . Values obtained from test probability is smaller than the alpha value of 0,05 . Overall, therefore, we can conclude that the independent variable (land, seed, fertilizer, and labor) together have a significant effect on the dependent variable rice production in the district was Gorontalo province.

4) Partial Test Results (t test)

Based on the analysis of data processing summary in Table 4.10 , it can be described the processing of the following data:

a. Land area

On the status of land ownership tenants owner acquired the t-test value of inputs acquired a land area of 4.386 which the significant value of the land area $(0,000)$ is smaller than the probability value of 0.05 . Then for tilling the land ownership status obtained the t-test value of inputs acquired a land area of 2,570 that the significant value of land $(0,014)$ is smaller than the probability value of 0.05 . It can be concluded that the land area of positive and significant impact on rice production in the district was Gorontalo province.

b. Seed

On the status of land ownership tenants owner's t-test values obtained obtained input seed production of 4.931 which seed significance value $(0.000)$ is smaller than the probability value of 0.05 . Then for tilling the land ownership status t-test values obtained 
obtained input seed production of 6.352 whose seed significance value $(0.000)$ is smaller than the probability value of 0.05 . It can be concluded that the seeds of positive and significant impact on rice production in the district was Gorontalo province.

c. Fertilizer

On the status of land ownership tenants owner's t-test values obtained obtained input fertilizer production amounted 1,161 which fertilizer significance value $(0.252)$ is greater than the probability value of 0.05 . Then for tilling the land ownership status obtained the t-test values obtained fertilizer production inputs at 0.933 that fertilizer significance value $(0.356)$ is greater than the probability value of 0.05 . It can be concluded that the fertilizer has a positive effect but not significant to rice production in the district was Gorontalo province.

d. Labor

On the status of land ownership tenants owner acquired the t-test values obtained labor inputs amounting to 2.029 were labor significance value $(0.048)$ is smaller than the probability value of 0.05 . Then the owners of land tenure for tenants obtained the t-test values obtained labor inputs that the significant value of 2,552 workers $(0,014)$ is smaller than the probability value of 0.05 . It can be concluded that labor and significant positive effect on rice production in the district was Gorontalo province.

e. Elasticity level for rice production efficiency in the district was

The test results of the technical efficiency of paddy each input is presented in Table 2 below:

Table 2 Results of Technical Efficiency

\begin{tabular}{cccc}
\hline No. & Commentary & $\begin{array}{c}\text { Owner } \\
\text { Cultivators }\end{array}$ & Cultivators \\
\hline 1 & $\mathrm{X} 1$ & $23856^{*}$ & $10239^{*}$ \\
2 & $\mathrm{X} 2$ & $2,281^{*}$ & $1,354^{*}$ \\
3 & $\mathrm{X} 3$ & $0.057 \mathrm{ne}$ & $0.051 \mathrm{ne}$ \\
4 & $\mathrm{X} 4$ & $3,305^{*}$ & $1,493^{*}$ \\
\hline \multicolumn{5}{l}{ Source: Data Processing, 2019}
\end{tabular}

Table 2 Based on the above it can be seen the results frontier of production of 0.131 to 0.129 for the owner tillers and cultivators which means rice production in the district was already not / not efficient. Then to get the results illustrate the efficiency of the production of each input is interpreted the results of testing of the technical efficiency of the following:

1) Land area

The average value of the technical efficiency of a land area of 36.723. The value is in the category that has not been efficient because of greater than 1. For the land from the owners and tenants of 23.856 to the tiller at 10.239. This shows between them in the utilization of land area for production activities are still not so effective, where for the owner of tenants still better than the tenants in the efficiency of land to obtain optimal production results. This is because by increasing the efficiency of the land area it will be able to save costs to the owner of $88.234 \%$, while tenants for tenants only able to make cost savings of up to $69.024 \%$ of the costs are often incurred.

2) Seed

The average value of the technical efficiency of 3.795 seed the value is in the category that is not efficient because of greater than 1. Efficiency seed for owners and tenants amounting to 2.281 to the tiller of 1,354 . So that both types of ownership lies in the inefficient criteria, which of these results the value of owners of larger tenants so that the use of the seeds, the owner of tenants still better than the owner of tenants. This is because with the addition of the seed, the owner of tenants will be able to make cost savings of up to $19.454 \%$, while for tenants will only be able to make cost savings of up to $14.644 \%$ seed 


\section{3) Fertilizer}

The average value of the technical efficiency of fertilizer by 0.058 the value is in the category of inefficient because it is smaller than 1 . The value of fertilizer efficiency for owners and tenants amounting to 0.057 to the tiller at 0.051 . This shows that both types of ownership lies in the inefficient criteria so that the use of fertilizers must pay attention to the SOP or the requirements to paddy fields. By reducing the use of fertilizers is the tenant farmers will be able to save up to $29.504 \%$, while for tenants which amounted to $22.754 \%$.

\section{4) Labor}

The average value of the technical efficiency of labor by 5.070 . The value is in the category that has not been efficient because of greater than 1 . The technical efficiency of labor to the owners of 3,305 tenants and to tenants at 1.493. This shows that the owners of tenants and tenants can still improve or add manpower to deal with the production of farmers should be increased so as to increase the production it will be savings up to $30.425 \%$ for farmers and tenants owner of $23.809 \%$ to the tiller. The addition of labor to the owners tenants should be done with caution due to the owner of tenants already in a position of nearly efficient or inefficient.

5) Status of Land Ownership

The average value of technical efficiency in tenure of 6,799 . The value is in the category that has not been efficient because of greater than 1 . So therefore it can be said that the status of land ownership from the owner of tenants must be considered as to the status of the owner can conduct greater oversight of the activity of the worker so the result is more efficient to production. So for optimal results in the future then the owner of the land should be doubled as well as penggarapn in order to become more efficient production.

\section{Influence of Input-Input Against Rice paddy production in the district was}

The test results showed that simultaneously land, seed, fertilizer, labor and positive and significant impact on rice production in the district was the province of Gorontalo to the value of the determinant of $79.50 \%$ for the tenants and the owner of $67.50 \%$ to the tiller. Then the partial results only variables of land, seed and labor are positive and significant effect on the dependent variable rice production in the district was Gorontalo province. The test results cobb douglas land ownership status variable that is positive indicates that farmers with penggrap owner pebih status as compared to smallholders in menghasilakn optimal production. Other factors that are out of production function model which allegedly also have an impact on rice production include soil fertility level and the influence of weather and climate as well as the intensity of pests and diseases.

These results are consistent with the opinion of Soekartawi (2011: 33) that farming has four key elements related to each other or with other terms as factors of farm production. The production factors, namely natural, labor, capital and management carried out by a farmer. The nature of the business of farming at first only to meet the food needs of their own to family farmers (subsistence). However, the nature of the business of farming evolved into a commercial nature in line with the increasing needs of life. As production activities, farming will ultimately take into account the costs incurred by the receipt obtained to determine the success of the business.

This is also supported by a statement from Muhyidin in Sudarman (2010: 17) production is a process in which goods and services are called input converted into goods and other services called outputs. Many types of activities that occur in the production process, which includes changes in the shape, place and time of use of the results of production. Each of these changes concerns the use of inputs to produce a desired output. So production includes all activities create goods and services. Agricultural production can be interpreted effort to maintain and develop a commodity for human needs. In the production process to add to or benefit then do the process from planting seedlings and maintained for the benefit or the result of an agricultural commodity. Production theory implies as to how should a farmer with a certain level of technology 
capable of combining various factors of production to produce a number of specific production.

The economic capacity of an area can be measured from the profits earned by the farmers in the form of income. This advantage depends on the conditions of production and marketing. The advantage is the difference between the cost (costs) and results (returns). This event occurred in a relatively short time and does not apply to long-term (Soekartawi, 2003). In contrast to the capital is not fixed or variable capital is the cost incurred in the production process and discharged in one of the production process, such as production costs incurred for the purchase of seeds, fertilizers, medicines, or paid for labor payment.

This shows that the farmer's status as the owner of tenants with larger land will be able to maximize the results. This is as according Raihan (2006) there are some reasons the owners seek to farmers penyakap ie, for customs, cultivation of conscience, the ability of the owner is limited in managing their land, ambition and economic reasons, those reasons can assess the nature of the life of the collective farmers, where the collective spirit and which refers to the self-orientation. The latter is a form of control over the owners of pure tenants are direct owners as land managers so that everything that happened on land it manages own responsibility. Although there are differences, they are basically farmers classify the area of land owned, land ownership seseorng determine social status. Farmers with vast arable land economic level is usually higher than in the rural landless farmers

\section{Elasticity level paddy rice production in the district was}

The test results showed that the average value of the technical efficiency of a land area of 36.723. The value is in the category that has not been efficient because of greater than 1. Thereby the state of the land area factor that is not efficient, which means the proportion of the additional factors of land will increase rice production or in other words, an effective planting on certain land area can increase the level of production. This shows that the need to optimize the input of the land area in increasing rice production through more efficient cropping systems. Then can also be seen that for the land from the owners and tenants of 23.856 to the tiller at 10.239 . This shows between them in the utilization of land area for production activities are still not so effective, where for the owner of tenants still better than the tenants in the efficiency of land to obtain optimal production results. This is because by increasing the efficiency of the land area it will be able to save costs to the owner of $88.234 \%$, while tenants for tenants only able to make cost savings of up to $69.024 \%$ of the costs are often incurred.

Agricultural land is said to be productive agricultural land if it can produce results in the field of farm production is satisfactory. To increase agricultural productivity, individual farmers are increasingly dependent on the resources of the area of the environment. The status of agricultural land that is classified as land owned, leased land, and land sekap. Value or price of land owned status are often more expensive than the land that does not belong. Owned land which is usually expressed by a land certificate as evidence of a higher price, this is one of them due to the lack of legal certainty of land ownership. Land or agricultural land use rights status or the right to cultivate, its value is relatively lower than the price of land owned status.

Then the results of the efficiency of seed was found that the average value of the technical efficiency of the seed of the value 3.795 is the category that is not efficient because of greater than 1. Thereby the state of the land area factor that is not efficient, which means the proportion of the addition of seed factors will Extra support in rice production in the district was. In doing farm use of seeds does not meet the standard that still need to be improved to produce paddy rice production is greater. Then the seeds can also be seen efficiency for owners and tenants amounting to 2.281 to the tiller of 1,354 . So that both types of ownership lies in the inefficient criteria, which of these results the value of owners of larger tenants so that the use of the seeds, the owner of tenants still better than the tenants. This is because with the addition of the seed, the owner of tenants 
will be able to make cost savings of up to $19.454 \%$, while for tenants will only be able to make cost savings of up to $14.644 \%$ seed. It can also be seen that the appropriate standard for 2 hectares of land that is as much as $25 \mathrm{~kg}$ of seed, but the reality for the average use of seeds per hectare by farmers tilling owner of $23,18 \mathrm{~kg} /$ hectare while the sharecroppers of $24,37 \mathrm{~kg} /$ hectare. This shows that the addition of seeds can still be done but with the proviso that there is no spacing is smaller than a predetermined standard.

As well as for the average value of the technical efficiency of fertilizer by 0.058 These values are in categories that are not efficient because it is smaller than 1 . Thereby the state of the land area factor that is not efficient, which means the proportion of the addition of fertilizer factor then it would not support the increase in production paddy rice in the district was. This is because the fertilizers used by farmers are already quite large but they have a great impact for farmers. Based on the results in the table above can be also known that the efficiency of fertilizer to the owners and tenants of 0.057 to 0.051 amounted tenants. This shows that both types of ownership lies in the inefficient criteria so that the use of fertilizers must pay attention to the SOP or the requirements to paddy fields. By reducing the use of fertilizers is the tenant farmers will be able to save up to $29.504 \%$, while for tenants, amounting to $22.754 \%$. This is because the fertilizers used by farmers are already quite large but they have a great impact for farmers. Capital is the most important factor in agricultural production, especially related material and labor costs. In other words, the existence of capital determines the level or kind of technology applied. Lack of capital caused a lack of input is given, causing a risk of failure or lack of results that will be accepted (Daniel, 2004: 21)

The average value of the technical efficiency of labor by 5.070. The value is in the category that has not been efficient because of greater than 1 . Thereby the state of the labor factor that is not efficient, which means the proportion of additional labor factor could be the reduction of the cost, but with the record large production increase of labor added the. Based on the table above also shows that the technical efficiency of labor to the owners of 3,305 tenants and to tenants at 1.493. This shows that the owners of tenants and tenants can still improve or add manpower to deal with the production of farmers should be increased so as to increase the production it will be savings up to $30,425 \%$ for farmers and tenants owner of $23,809 \%$ to the tiller.

The addition of labor to the owners tenants should be done with caution due to the owner of tenants already in a position of nearly efficient or inefficient .. Increased productivity is increasingly unable or difficult to increase because of the labor force remained were elderly and women. While more young workers are not interested in the agricultural sector as more interested in the urban industrial sector (Daniel, 2004: 88). These results are also consistent with the statement of Suratiyah (2006: 34), which states that the workforce is one of the decisive element, especially for farming greatly depending on the season. Labor shortages resulted in the resignation of planting so the effect on plant growth, productivity and product quality. Farm households are generally very limited in terms of his ability to seed, the role of family labor is crucial. If they can accomplish by their own family labor it is not necessary to hire outside labor, which saves costs.

\section{CONCLUSION}

The results found that the simultaneous analysis land, seed, fertilizer, labor and positive and significant impact on rice production in the district was the province of Gorontalo to the value of the determinant of $79,50 \%$ for the tenants and the owner of $67,50 \%$ to the tiller. Then the partial results only variables of land, seed and labor are positive and significant impact on rice production in the district was Gorontalo province. The coefficient of land ownership that is positive indicates that farmers with its status as the owner of penggrap better than the sharecroppers in generating optimal production.

Results of the analysis showed that the efficiency of land, seeds and labor have a greater value than one that is in the category yet efficient. Then for fertilizer has a smaller 
value than one that is in the category inefficient. The results of the comparison in terms of land status beradasarkan Frontier analys Stohastic efficiency analysis and technical efficiency was found that the owner of tenants is better than the tenants in farm production input efficiency of paddy in the district was.

\section{REFERENCES}

Darwanto. 2003. Efficiency Analysis of Rice Farming in Java Tengah. Thesis. Diponegoro University. Semarang.

Department of Agriculture. 2017. Food Crops and Horticulture. Boalemo District Agriculture Office, Gorontalo.

Erni. 2018. Analysis of the Efficient Use of Factor - Factor Production and Use of Farm Irrigation In Rice In Gorontalo regency. Gorontalo State University. Gorontalo.

Friyanto, S and Sumaryanto. 2013. Use of Factor Analysis In the Lowland Rice Farming. Journal Institut Pertanian Bogor. Bogor

Hanafie, R. 2010. Pengantar IImu Pertanian. Yogyakarta (ID): ANDI. Yogyakarta

Hernanto, 1998. Ilmu Usahatani. Penebar Swadaya, Jakarta

Made, A., Ketut S and Ambarwati. 2012. Rice Rice Efficiency Analysis (Case Study in the District Subak Marga Tabanan regency). Journal of Agribusiness. Udayana University. Bali.

Rahim, Abdul dan Diah Retno Dwi Hastuti. 2007. Ekonomika Pertanian (Pengantar, Teori dan Kasus) Penebar Swadaya. Jakarta

Rizal Doda. 2018. Analysis of Time Allocation Working On Rice Farming in the city of Gorontalo State Gorontalo.Universitas. Gorontalo.

Safrijon. 2014. Factors Affecting the Production of Rice Intensification Quality Development Program (PMI) in the village of Batang Kumu Tambusai District of Rokan Hulu. Journal.Universitas Sand Watering, Tokan Hulu.

Siregar, Hadrian. 2003. Budidaya Tanaman Padi di Indonesia. Sastra Budaya, Yogyakarta

Soekartawi, A Soeharjo, JL Dillon, and JB Hardker. 2003. Usahatani Science and Research Development for Enterprises Kecil.Universitas Indonesia. Jakarta.

Umar. 2001. Research Methods. PT. Gramedia Pustaka Utama. Jakarta. 